\title{
PENTINGNYA DOKUMENTASI KEPERAWATAN DALAM SETIAP TINDAKAN ASUHAN KEPERAWATAN
}

\author{
Ria Oktaviany \\ riariaok29@gmail.com
}

\begin{abstract}
Abstrak
Latar Belakang : Perawat adalah profesi yang berada paling dekat dan paling lama dengan pasien. Tak bisa dipungkiri bahwa keseluruhan tindakan keperawatan pasti berinteraksi dengan pasien. Keterbatasan waktu dan tenaga membuat perawat harus bekerja sesuai shift. Pergantian shift ini sangat rentan terjadinya miskomunikasi antara perawat di shift sebelumnya dengan shift yang baru. Metode : Metode yang digunakan untuk menemukan pemtingnya dokumentasi keperawatan dalam setiap tindakan asuhan keperawatan adalah dengan menggunakan kajian pustaka. Hasil : Berdasarkan hasil literatur dokumentasi keperawatan daam setiap tindakan asuhan keperawatan itu sangat penting dan mutlak harus dilakukan.

Pembahasan : Dokumentasi keperawatan merupakan bukti hukum yang dapat dipergunakan untuk mendukung perawat ketika menghadapi permasalahan hukum. Penutup : Beberapa tujuan pentinya dokumentasi keperawatan adalah untuk menjamin kontinuitas asuhan keperawatan, sebagai sarana edukasi, sarana pengkajian, penelitian, audit dan pemantauan, serta perlindungan diri perawat.

\section{Latar Belakang}

Perawat adalah profesi yang berada paling dekat dan paling lama dengan pasien. Tak bisa dipungkiri bahwa keseluruhan tindakan keperawatan pasti berinteraksi dengan pasien.

Keterbatasan waktu dan tenaga membuat perawat harus bekerja sesuai shift. Pergantian shift ini sangat rentan terjadinya miskomunikasi antara perawat di shift sebelumnya dengan shift yang baru. Miskomunikasi yang terlihat sepele ternyata dapat membahayakan nyawa klien. Hal ini pula yang dapat mengakibatkan tingginya angka kejadian tidak diharapkan (KTD) yang terjadi di rumah sakit. Tentu dalam pelayanan keperawatan, seorang perawat profesional dituntut dan bersumpah untuk melindungi klien agar tidak terjadi KTD karena kelalaian perawat.
\end{abstract}


Pelayanan keperawatan merupakan bagian integral dari pelayanan kesehatan di rumah sakit yang mempunyai peranan besar terhadap pencapaian efisiensi, mutu dan citra rumah sakit di mata masyarakat karena perawat adalah tenaga kesehatan terbanyak dan tenaga kesehatan yang perannya sangat besar dalam merawat klien. Kualitas pelayanan keperawatan di rumah sakit tidak akan berjalan baik apabila proses keperawatan yang dilaksanakan tidak terstruktur dengan baik. Untuk mencapai asuhan keperawatan yang komprehensif dan berkualitas maka disusun proses keperawatan. Proses keperawatan ini berguna agar asuhan keperawatan dapat berjalan dengan baik dan kontunuitas asuhan berjalan dengan lancar.

Praktek keperawatan yang benar sesuai dengan proses keperawatan telah disusu dalam Permenkes RI Nomor. HK.02.02/Menkes/148/ I/2010 tentang izin dan penyelenggaraan praktik keperawatan.Hal ini juga telah ditetapkan dalam SK Menkes No.436/Menkes/SK/VI/1993 tetang standar pelayanan rumah sakit. Pada kenyataannya meskipun telah ada peraturan tentang praktek keperawatan dan rekam medik, sebagian perawat masih merasa proses keperawatan bukanlah suatu kewajiban profesi melainkan sebagai suatu beban. Pernyataan ini didukung dengan hasil evaluasi dokumentasi asuhan keperawatan pada beberapa rumah sakit yang menunjukkan bahwa kemampuan perawat mendokumentasikan asuhan keperawatan rata-rata kurang dari $60 \%$, sedangkan hasil evaluasi dokumentasi keperawatan pada dua rumah sakit jiwa rata-rata kurang dari $40 \%$ yang memenuhi kriteria (Akemat K.B.A, 2012). Asuhan keperawatan yang tepat adalah pelayanan keperawatan yang diberikan perawat kepada pasien melalui tahap pengkajian, diagnosa, perencanaan, implementasi, evaluasi dan dokumentasi.

Angka yang begitu tinggi menyadarkan kita bahwa pentingnya kesadaran melakukan dokumentasi keperawatan. Hal tersebut tentu untuk melindungi perawat dari ranah hukum dan juga melindungi nyawa klien. Dokumentasi keperawatan harus memenuhi syarat yaitu berdasarkan fakta, akurat, ringkas, lengkap, terorganisir, kesesuaian waktu, dan mudah dibaca. Mutu pelayanan keperawatan di rumah sakit dapat dikatakan berkualitas apabilaperawat memiliki keterampilan, kecepatan, kemudahan dan ketepatan dalam melakukan tindakan praktek keperawatan (Supriyanto dan Ratna, 2011). Tentu semuanya akan terpenuhi bila perawat melakukan tahapan proses keperawatan dan dkumentasi keperawatan tanpa terlewat satu langkah pun.

\section{Metode}


Metode yang digunakan untuk menemukan pemtingnya dokumentasi keperawatan dalam setiap tindakan asuhan keperawatan adalah dengan menggunakan kajian pustaka. Maksud metode kajian pustaka disini adalah penulis mengumpulkan berbagai sumber literatur yang memiliki keterkaitan dengan topik yang dibahas ini. Penulis mengandalkan hasil penelitian dari beberapa jurnal, skripsi, ebook, dan beberapa karya ilmiah lain yang relevan dengan topik yang diambil penukis. Setelah dikumpulkan, karya-karya ilmiah tadi akan dianalisis serta dikaji satu per satu untuk mendapatkan jawaban dari pentingnya dokumentasi keperawatan dalam setiap tindakan asuhan keperawatan.

\section{Hasil}

Berdasarkan hasil literatur dokumentasi keperawatan daam setiap tindakan asuhan keperawatan itu sangat penting dan mutlak harus dilakukan. Dokumentasi keperawatan tidak hanya berguna untuk pasien melainkan perawat juga. Untuk menjamin kontinuitas asuhan keperawatan perlu dilakukan dokumentasi keperawatan agar tidak terjadi kesalahan dalam.pemberian asuhan keperawatan saat pergantian shift kerja. Dokumentasi keperawatan juga merupakan pendokumentasian yang akurat sebagai satu pertahanan diri terbaik terhadap tuntutan baik yang melibatkan hukum atau tidak. Menurut Nurhafni, 2013, dokumentasi penting untuk meningkatkan efisiensi perawatan klien secara individual.

Keperawatan adalah salah satu profesi yang berperan penting dalam penyelenggaraan upaya menjaga mutu pelayanan kesehatan di rumah sakit. Mutu pelayanan kesehatan adalah derajat kesempurnaan pelayanan kesehatan yang dapat memuaskan setiap pemakai jasa pelayanan kesehatan serta yang menyelenggarakannya sesuai dengan standar dan kode etik profesi yang telah ditetapkan dengan menyesuaikan potensi sumber daya yang tersedia secara wajar, efisien dan efektif serta diberikan secara aman, dan memuaskan sesuai norma-norma yang berlaku. Untuk dapat meningkatkan mutu pelayanan kesehatan, perawat memiliki proses keperawatan yang dapat menuntun perawat kepada tindakan asuhan keperawatan yang berkuliatas.

Proses keperawatan merupakan proses pemecahan masalah yang dinamis dan terstruktur dalam usaha memperbaiki atau memelihara pasien sampai taraf optimum melalui suatu pendekatan yang sistematis untuk mengenal dan membantu memenuhi kebutuhan khusus pasien serta memandirikan pasien untuk mencapai kesejahteraan kesehatannya. Tahapan proses 
keperawatan dimulai dari pengkajian, diagnosa kesehatan, perencanaan asuhan keperawatan, implementasi asuhan keperawatan, evaluasi hasil, dan kelimanya harus didokumentasikan. Dokumentasi ini sangat berguna untuk menjalankan asuhan keperawatan secara kontinu dan berfungsi untuk melindungi perawat terhadap tindakan yang telah dilakukannya.

\section{Pembahasan}

Fisbach (1991), mengatakan bahwa dokumentasi adalah informasi yang tertulis tentang status perkembangan kondisi kesehatan pasien serta semua kegiatan asuhan keperawatan yang di lakukan oleh perawat. Sedangkan menurut Nurhafini (2013) dokumentasi merupakan suatu dokumen yang berisi data lengkap, nyata, dan tercatat bukan hanya tentang tingkat kesakitan pasien tetapi juga jenis dan kualitas pelayanan kesehatan yang di berikan.

Pelaksanaan dokumentasi proses keperawatan penting sebagai salah satu alat ukur untuk mengetahui, memantau dan menyimpulkan suatu pelayanan asuhan keperawatan yang diselenggarakan di rumah sakitv(Fisbach, 1991). Pengisian dokumentasi keperawatan yang tidak memenuhi standar dapat mengakibatkan kesalahan diagnosa dan pemberian tindakan asuhankeperawatan yang tidak tepat kepada pasien. Dokumentasi keperawatan merupakan bukti hukum yang dapat dipergunakan untuk mendukung perawat ketika menghadapi permasalahan hukum. Dari penjelasan tersebut dapat disimpulkan tujuan penting dokumentasi keperawatan adalah :

- Menjamin kontinuitas asuhan keperawatan pada klien

Adanya dokumentasi keperawatan yang jelas dan terstandar akan membuat asuhan keperawatan terarah. Apabila tidak di dokumentasikan dengan benar maka kemungkinan terjadinya kejadian tidak diharapkan (KTD) akan lebih besar. Apabila KTD tidak dapat ditekan perawat tidak hanya dirugikan secara profesi melainkan secara ekonomi dan juga sosial. Perawat akan dituntut karena asuhan keperawatan yang tidak aman dan juga profesi perawat akan memjadi buruk di mata masyarakat. Pentingnya dokumentasi keperawatan disini adalah apabila setiap perawat melakukan pendokumentasian dalam setiap tindakannya maka tuntutan akan human error juga dapat ditekan. Perawat yang akan menjalani shift tidak akan bingung apa yang selanjutnya harus dilakukan apabila perawat di shift sebelumnya mencatat setiap tindakan yang telah dilakukan dengan jelas. 
- Edukasi

Dengan adanya dokumentasi peserta didik dan mahasiswa keperaeatan dapat belajar tentang pola yang harus di temui dalam berbagai masalah kesehatan dan menjadi mampu untuk mengantisipasi tipe perawatan yang tepat sesuai dengan kebutuhan klien.

- Pengkajian

Dokumentasi berisi catatan yang dapat memberikan data yang di gunakan perawat untuk mengidentifikasi dan mendukung diagnosa keperawatan dan merencanakan intervensi yang sesuai.

- Penelitian

Perawat dan peneliti dapat menggunakan catatan klien selama study riset untuk mengumpulkan informasi tentang faktor-faktor tertentu yang berkaitan dengan kondisi klien serta inovasi inovasi yang dapat digunakan untuk meningkatkan asuhan keperawatan.

- Audit dan Pemantauan

Dokumentasi keperawatan berisi tinjauan teratur tentang informasi pada catatan klien memberi dasar untuk evaluasi tentang kualitas dan ketepatan perawat yang diberikan dalam suatu institusi.

\section{- Pertahanan Diri Perawat}

Adanya dokumentasi yang jelas dan terstandar membuat perawat dapat terhindar dari adanya tuntutan yang tidak benar mengenai dirinya. Atau jikapun ditemukan adanya human error perawat dapat mempertanggungjawabkan hal tersebut sebanding dengan pelanggaran yang telah dilakukannya.

Dokumentasi asuhan keperawatan juga tidak boleh dilakukan asal-asalan harus akurat, lengkap dan sesuai standar. Apabila asuhan keperawatan tidak didokumentasikan dengan akurat lengkap, dan benar maaka sulit untuk membuktikan bahwa asuhan keperawatan telak dilakukan dengan benar (Hidayat, 2004).

Tahapan dokumentasi keprawatan sesuai dengan proses keperawatan dapat disimpulkan sebagai berikut : 


\section{a) Dokumentasi Pengkajian Asuhan Keperawatan}

Kriteria pengkajian keperawatan, meliputi pengumpulan data dilakukan dengan cara anamnesi, observasi, pemeriksaan fisik, serta dari pemeriksaan diagnosis. Sumber data adalah klien, keluarga,atau orang yang terkait dengan klien, tim kesehatan, rekam medis, dan catatan lain. Semuanya perlu didokumentasikan dengan jelas dna benar agar dapat menentukan asuhan keperawatan yang tepat.

\section{b) Dokumentasi Diagnosa Asuhan Keperawatan}

Diagnosa yang telah ditentukan perawat setelah melakukan pengkajian juga harus didokumentasikan dengan benar. Tahap diagnosa ini adalah tahap pengambilan keputusan pada proses keperawatan, yang meliputi identifikasi apakah masalah klien dapat dihilangkan, dikurangi atau dirubah masalahnya melalui tindakan asuhan keperawatan.

\section{c) Dokumentasi Rencana Asuhan Keperawatan}

Rencana asuhan keperawatan tertulis mengatur pertukaran informasi oleh perawat dalam laporan pertukaran dinas atau shift. Rencana keperawatan yang didokumentasikan juga harus mencakup kebutuhan klien jangka panjang (Potter \& Perry, 2005).

\section{d) Dokumentasi Pelaksanaan (Implementasi) Asuhan Keperawatan}

Dokumentasi pelaksanaan tindakan keperawatan harus diikuti oleh pencatatan yang lengkap dan akurat terhadap suatu kejadian dalam proses asuhan keperawatan baik dari respon klien, keberhasilan tindakan, dan reaksi fisik pasien selama tindakan.

\section{e) Dokumentasi Evaluasi Asuhan Keperawatan}

Evaluasi dalam dokumentasi asuhan keperawatan diantaranya adalah evaluasi formatif, yang merupakan hasil observasi dan analisa perawat terhadap respon klien segera pada saat dan setelah intervensi keperawatan dilaksanakan. Yang kedua adalah evaluasi sumatif dimana evaluasi ini merupakan rekapitulasi dan kesimpulan dari observasi dan analisa status kesehatan klien sesuai dengan kerangka waktu yang telah ditetapkan pada tujuan keperawatan.

Meski mengetahui pentingnya dokumentasi keperawatan dalam setiap tindakan asuhan keperawatan masih banyak perawat yang menganggap bahwa dokumentasi keperawatan itu 
adalah suatu beban bagi mereka. Apabila beban kerja perawat terlalu berat maka kinerja perawat menjadi tidak maksimal, oleh karena tingginya beban kerja tersebut kegiatan pendokumentasian pun tidak maksimal karna dianggap sebagai beban tambahan.

Beberapa hambatan yang mungkin ditemukan perawat dalam mendokumentasikan tindakan asuhan keperawatannya adalah tidak cukup waktu untuk menuliskan setiap tindakan yang telah diberikan pada lembar format dokumentasi keperawatan, tidak adanya pengadaan lembar format dokumentasi keperawatan oleh institusi tidak semua tindakan diberikan pada pasien dapat di dokumentasikan dengan baik karena lembar format yang ada tidak menyediakan tempat (kolom untuk menuliskannya).

Salah satu cara penanganannya adalah dengan melakukan dokumentasi keperawatan melakukan teknik komputerisasi. Adanya komputer dalam sistem manajemen keperawatan membut kegiatan pendokumentasian lebih mudah, murah, efisien dan efektif (Anggadini, 2013). Faktor yang dapat meningkatkan prestasi kerja, motivasi dan kepuasan kerja dalam pelaksanaan dokumentasi keperawatan ini dapay dilakukan dengan pemberian kompensasi, berupa kompensasi finansial dan non finansial (Simamora, 2004).

\section{Penutup}

Fisbach (1991), mengatakan bahwa dokumentasi adalah informasi yang tertulis tentang status perkembangan kondisi kesehatan pasien serta semua kegiatan asuhan keperawatan yang di lakukan oleh perawat. Pelaksanaan dokumentasi proses keperawatan penting sebagai salah satu alat ukur untuk mengetahui, memantau dan menyimpulkan suatu pelayanan asuhan keperawatan yang diselenggarakan di rumah sakitv(Fisbach, 1991).

Beberapa tujuan pentinya dokumentasi keperawatan adalah untuk menjamin kontinuitas asuhan keperawatan, sebagai sarana edukasi, sarana pengkajian, penelitian, audit dan pemantauan, serta perlindungan diri perawat. 


\section{Daftar Pustaka}

Amalia., Malini, H., Yulia, S. (2018). Kepuasan Perawat terhadap Kualitas Pendokumentasian Asuhan Keperawatan Berbasis Komputer. Jurnal Keperawatan Indonesia, 21(3), 169-179.

Andri, F., Indra, R., Susmarini, D. (2015). Analisis Faktor-faktor yang Memperngaruhi Perawat dalam Memenuhi Kelengkapan Dokumentasi Keperawatan di IGD Rumah Sakit Wilayah Pontianak Kalimantan Barat. Jurnal Medika Respati, 10(4), 49-59.

Kasim, M., Abdurrouf, M. (2016). Peningkatan Kualitas Pelayanan dan Pendokumentasian Asuhan Keperawatan dengan Metode Tim. Nurseline journal, 1(1), 62-72.

Khoirunnisa, D., Prayogi, A.S., Arini, T. (2019). Beban Kerja Perawat Berhubungan Dengan

Kelengkapan Pendokumentasian Asuhan Keperawatan Rawat Inap RSUD Panembahan Senopati Bantul. Jurnal Teknologi Kesehatan, 15(1), 16-24.

M, Bara., B, Suryati. (2014). Hubungan Motivasi Perawat dengan Pelaksanaan Pendokumentasian Asuhan Keperawatan di Ruang Rawat Inap RSUD Pasar Rebo. Jurnal Health Quality, 5(1), 919.

Muhith, A., Nursalam. (2012). Mutu Asuhan Keperawatan Berdasarkan Analisis Kinerja Perawat dan Kepuasan Perawat dan Pasien. Jurnal Ners, 7(1), 47-55

Rum, M.R. (2019). Faktor-Faktor yang mempengaruhi Kepatuhan Perawat dalam Pendokumentasian Asuhan Keperawatan. Jurnal Ilmiah Kesehatan, 18(1), 4-9.

Simamora. (2004). Manajemen Sumber Daya Manusia. Yogyakarta: Sekolah Tinggi Ilmu Ekonomi YKPN.

Simamora, R. (2009). Dokumentasi Proses Keperawatan.

Simamora, R. H., Purba, J. M., Bukit, E. K., \& Nurbaiti, N. (2019). Penguatan Peran Perawat Dalam Pelaksanaan Asuhan Keperawatan Melalui Pelatihan Layanan Prima. JPPM (Jurnal Pengabdian Dan Pemberdayaan Masyarakat), 3(1), 25-31.

Sumilat, N.P. (2017). Standar Pendokumentasian Asuhan Keperawatan di BLUD RSUD Kota Baubau. Skripsi. Universitas Islam Negeri Alauddin. Tidak Dipublikasikan. 
Tarigan, R., Handiyani, H. (2019). Manfaat Implementasi Dokumentasi Asuhan Keperawatan Berbasis Komputerisasi Dalam Meningkatkan Mutu Asuhan Keperawatan. JurnalJurnal Ilmiah Kesehatan Pencerah, 8(2), 110-116. 